\title{
Facilitation of seagrass Zostera marina productivity by suspension-feeding bivalves
}

\author{
Charles C. Wall*, Bradley J. Peterson, Christopher J. Gobler \\ School of Marine and Atmospheric Sciences, Stony Brook University, Stony Brook, New York 11794-5000, USA
}

\begin{abstract}
Seagrasses and suspension feeders are both critical ecosystem engineers in estuaries. Seagrass beds are important structural habitats, and suspension feeders, when abundant, can regulate phytoplankton densities. Furthermore, there may be mutual facilitation of growth and recruitment between seagrasses and suspension-feeding bivalves. In a series of mesocosm experiments, the effects of environmentally realistic densities of 3 different suspension-feeding bivalves (Mercenaria mercenaria, Crassostrea virginica, Mytilus edulis) on the growth of eelgrass Zostera marina in a eutrophied environment were examined. Experimental treatments with bivalves consistently yielded significantly lower chlorophyll a concentrations $(\mathrm{p}<0.05)$, and most bivalve treatments also showed significant increases in light penetration $(\mathrm{p}<0.05)$. Eelgrass productivity was measured by leaf area growth, and varied from $0.318 \pm 0.018$ to $0.832 \pm 0.036 \mathrm{~cm}^{2} \operatorname{shoot}^{-1} \mathrm{~d}^{-1}$ (mean $\pm \mathrm{SE}$ ); leaf area productivity was always significantly higher (on average, $48 \pm 9.3 \%$ higher) in the treatments with the highest density of bivalves compared to a control without bivalves $(p<0.05)$. The data indicate that clearance of the water column, and the subsequent increase in light penetration, was the primary mechanism by which suspension-feeding bivalves facilitated the growth of eelgrass. These findings suggest that healthy populations of suspension-feeding bivalves can mitigate the effects of estuarine eutrophication and can facilitate the growth of seagrass in degraded, light-limited habitats.
\end{abstract}

KEY WORDS: Zostera marina - Crassostrea virginica - Mercenaria mercenaria • Mytilus edulis · Seagrass · Eelgrass · Eutrophication · Bivalves · Suspension feeders · Mesocosms

\section{INTRODUCTION}

Estuaries and other coastal ecosystems have suffered multiple anthropogenic insults during the past century, including pollution, eutrophication, overfishing of fish and shellfish, introduction of invasive species, and loss of key habitats, such as seagrass beds (Valiela et al. 1992, Nixon 1995, Jackson 2001, Newell \& Koch 2004, Lotze et al. 2006, Valiela 2006). Seagrass beds are a valuable habitat in many temperate and tropical estuaries, providing structural habitat complexity (Heck \& Wetstone 1977), damping waves and trapping sediment (Newell \& Koch 2004), modifying the sedimentary environment (Reise 2002), providing a settlement site for juvenile bivalves (Bologna et al. 2005), and furnishing benthic primary production. Due to the array of ecological services provided by seagrass beds, they should be considered 'ecosystem engineers' (Reise 2002, Bruno et al. 2003).
Eutrophication of coastal waters can have a multitude of adverse impacts on affected ecosystems, including nuisance algal blooms, hypoxia, and the subsequent loss of marine life and habitats (Nixon 1995, de Jonge et al. 2002). Dense phytoplankton blooms or macroalgal growth resulting from eutrophication can reduce light penetration to the benthos and shade seagrass beds (Valiela et al. 1992, Duarte 1995, Hauxwell et al. 2001, Gobler et al. 2005). Anthropogenic nutrient loading can also increase seagrass epiphyte loads, which, in turn, decrease the quantity and quality of light at leaf surfaces and subsequently decrease seagrass productivity (Duarte 1995). Newell \& Koch (2004), through a combination of modeling and field studies in Chesapeake Bay, have shown that the seagrass Ruppia maritime, which does not grow deeper than $3 \mathrm{~m}$ under optimal conditions, is very sensitive to decreases in light penetration due to algal blooms or 
resuspended sediment. Other experimental studies have demonstrated the decline of Zostera marina in response to nutrients (Taylor et al. 1999, Bintz et al. 2003), light reduction (Bintz \& Nixon 2001), and epiphyte load (Brush \& Nixon 2002).

One guild of species that might facilitate the growth of seagrass is suspension-feeding bivalves. Various species of bivalves live in, on, or near seagrass beds, and the filtration provided by bivalves has the potential to control eutrophication (Officer et al. 1982) and significantly affect carbon cycling (Doering et al. 1986). By depositing solid, nutrient-rich fecal material and pseudo-feces, bivalves mediate a flux of organic matter and nutrients out of the water column and into the sediments (Smaal \& Prins 1993). This nutrient enrichment of sediments can increase the growth of seagrass, since seagrasses absorb most of their nutrients from the sediment through their roots and not from the water column (Peterson \& Heck 1999). Reusch et al. (1994) and Peterson \& Heck (1999, 2001) showed that Mytilus edulis and Modiolus americanus, respectively, could increase seagrass productivity through sediment nutrient enrichment. By clearing algal populations and other suspended particles from the water column, bivalves may serve as a control on marine (Cerrato et al. 2004) and freshwater (Heath et al. 1995) algal blooms. While the work of Cerrato et al. (2004) and the modeling efforts of Newell \& Koch (2004) suggest that bivalve filtration could increase ambient light and perhaps enhance seagrass productivity, no previous study has directly examined this relationship.

During the past century, many estuarine bivalve populations have suffered from overharvesting and habitat loss (Jackson 2001, Lotze et al. 2006), an occurrence which could have secondary negative impacts on seagrass beds. Since bivalves may serve as a natural control on eutrophication (Officer et al. 1982), the loss of these populations could result in decreases in light reaching the benthos, a factor which often limits eelgrass productivity in estuaries (Dennison \& Alberte 1985, Bintz \& Nixon 2001). Great South Bay, a shallow estuary on Long Island's south shore, has experienced an increase in eutrophication and frequent algal blooms, including harmful 'brown tides' (Aureococcus anophagefferens; Gobler et al. 2005). These changes were concurrent with the loss of seagrass beds (Zostera marina; Dennison et al. 1989) and the removal of the dominant suspension-feeding bivalve (Mercenaria mercenaria; Cerrato et al. 2004). Similarly, in Chesapeake Bay, the loss of oyster Crassostrea virginica populations has been hypothesized to have contributed to the demise of $Z$. marina in this system (Jackson 2001, Newell \& Koch 2004, Kemp et al. 2005, Lotze et al. 2006).

For the present study, the effects of various suspension-feeding bivalves on the growth of the seagrass
Zostera marina were examined. A eutrophied system was simulated by loading nutrients to mesocosms containing various combinations of seagrass and bivalves. These experiments were designed to test the hypothesis that, in a eutrophied estuary, algal biomass would decrease and light penetration and seagrass productivity would increase as a function of bivalve filtration pressure.

\section{MATERIALS AND METHODS}

Five mesocosm experiments were carried out at the Stony Brook-Southampton Marine Science Center on Old Fort Pond in Southampton, New York, from 18 May 2006 to 10 October 2006. Old Fort Pond exchanges tidally with Shinnecock Bay, one of the major Long Island south shore estuaries. The experiments were carried out in a series of $300 \mathrm{l}$ polyethylene tanks (Nalgene; depth $=122 \mathrm{~cm}$, inside diameter $=60 \mathrm{~cm}$ ), which have been used successfully in the past to examine the impacts of filer-feeding bivalves on pelagic algal communities (Cerrato et al. 2004). Prior to each experiment, all tanks were scrubbed, rinsed with fresh water, and then filled with seawater from Old Fort Pond. The mesocosms were $~ 90 \%$ immersed in Old Fort Pond to maintain a uniform ambient temperature. Small aquarium pumps (Rio 180 Mini, pumping rate: $456 \mathrm{l} \mathrm{h}^{-1}$ ) were added to mix the water column of each mesocosm, but were suspended only a few centimeters below the surface to minimize re-suspension of sediments or biodeposits. Measurements taken at the start of each experiment and every 1 to $2 \mathrm{~d}$ during experiments included temperature, salinity, dissolved oxygen, chlorophyll a (chl a), and light attenuation. Surface and bottom readings of temperature and salinity during experiments confirmed that aquarium pumps kept the mesocosms well-mixed during experiments. Chl a was measured by filtering mesocosm samples onto replicated GF/F filters and $5 \mu \mathrm{m}$ polycarbonate filters, freezing and extracting in acetone, and measuring fluorescence with a Turner Trilogy fluorometer (Parsons et al. 1984). Light was measured using a LiCor LI-193 spherical underwater quantum sensor, and the light attenuation coefficient, $K_{\mathrm{d}}$, was calculated from incoming irradiance and light at the bottom of the mesocosm using the following formula:

$$
K_{\mathrm{d}}=-\ln (\text { irradiance at depth/incoming irradiance) } / z
$$

To stimulate anthropogenic nutrient loading, all mesocosms received daily additions of ammonium (10 $\mu \mathrm{M}$ final concentration) and orthophosphate (0.625 $\mu \mathrm{M}$ final concentration), a nutrient-loading rate that mimics rates found within more eutrophic regions of Long Island (Gobler \& Boneillo 2003). 
Each mesocosm in all of the experiments contained a weighted plastic planter with clean sand and 12 shoots of the seagrass Zostera marina. Eelgrass shoots, 20 to $30 \mathrm{~cm}$ long, were harvested from eastern Shinnecock Bay on the day that each experiment commenced. Eelgrass was sorted to remove reproductive shoots, rinsed in seawater, separated into individual shoots with a segment of the attached rhizome, and marked with a small pinhole at the top of the sheath using an 18 gauge needle, according to the method of Zieman (1974). Twelve marked shoots were randomly assigned to each mesocosm, gently buried in the planter, making sure the roots were intact and covered with sand, and the planters were carefully lowered to the bottom of the mesocosm.

Hard clams Mercenaria mercenaria and oysters Crassostrea virginica were locally harvested and obtained from seafood markets, while blue mussels Mytilus edulis were collected by hand from Shinnecock Bay. Prior to each experiment, all bivalves were placed in a flowing seawater table for approximately $24 \mathrm{~h}$ to acclimate to the temperature and salinity of Old Fort Pond. To eliminate any impact that the biodeposits might have on elevating productivity, bivalves and eelgrass shoots were separated by plastic dividers within the planter trays. Hard clams were partially buried with the siphon facing up, while mussels and oysters were simply placed on top of the planter.

At the end of each experiment, the planters with their seagrass shoots and bivalves were carefully removed from each mesocosm. Seagrass shoots that detached from the planter during the course of the experiment were not collected for further analysis. In the laboratory, the daily aboveground production and leaf epibiont biomass $\left(\right.$ shoot $\left.^{-1}\right)$ were determined. Seagrass shoots were collected and their growth was determined. Seagrass productivity was calculated for each experiment as leaf area productivity $\left(\mathrm{cm}^{2}\right.$ shoot $^{-1}$ $\mathrm{d}^{-1}$ ) based on the growth of new leaf material from the shoots in each mesocosm (Zieman 1974). Epibiont mass was determined by scraping fouling organisms and algae from each leaf, then drying them to a constant mass $( \pm 0.01 \mathrm{mg})$ in an oven at $70^{\circ} \mathrm{C}$.

The bivalves were retained after each experiment for the determination of lengths, width, heights, and ashfree dry weights (AFDW). Twelve individuals were randomly selected for a clearance rate measurement using one of the methods outlined by Riisgard (2001). The 12 bivalves were placed in 11 containers filled with water from one of the control mesocosm tanks, which typically had high levels of chl a $\left(>20 \mu \mathrm{g} \mathrm{l}^{-1}\right)$. Experiments commenced when individuals were open and filtering. Chl a samples taken before filtration and after a known length of time yielded a clearance rate for each individual according to the formula:

\author{
Clearance rate $=$ \\ (volume / time) $\times \ln ($ initial chl a / final chl a)
}

The 12 individuals that were used for the clearance rate measurements were then shucked, dried at $70^{\circ} \mathrm{C}$, weighed, combusted at $450^{\circ} \mathrm{C}$, and weighed again to determine the AFDW of their tissues. These weights were used to normalize the clearance rates to tissue weight rather than to individual.

A 'community' clearance rate for each mesocosm was estimated from these data using the average individual clearance rate and the number of individuals in the tank. An estimated turnover time for the entire tank volume to pass through the bivalves was calculated for each tank by dividing the tank volume by this community clearance rate.

Expt 1. Expt 1 was carried out for $18 \mathrm{~d}$ from 18 May to 5 June using the hard clam Mercenaria mercenaria. There were 2 experimental treatments with $16 \mathrm{M}$. mercenaria tank $\mathrm{k}^{-1}$ for a density of 57 ind. $\mathrm{m}^{-2}$ and a control treatment with no bivalves added ( $\mathrm{n}=4$ for each treatment). This density is comparable to historical densities of 53 to 105 clams m ${ }^{-2}$ for Great South Bay (Cerrato et al. 2004). Modern densities of M. mercenaria in Great South Bay are 2 magnitudes of order lower, ranging from 0.5 to 2 ind. $\mathrm{m}^{-2}$ (B. J. Peterson pers. obs.). For all experiments, replicates for each treatment were placed among the array of mesocosms using a randomized blocks design (Sokal \& Rohlf 1995) to minimize any effects due to placement of the mesocosm tank.

Expt 2. Expt 2 was carried out for 12 d from 7 to 19 June, also with hard clams. There were 2 experimental treatments with 4 and 8 Mercenaria mercenaria added for densities of 14 and 29 ind. $\mathrm{m}^{-2}$, respectively, and 1 control treatment ( $\mathrm{n}=4$ for each treatment).

Expt 3. Expt 3 was carried out for 8 d from 20 to 28 June, this time with the oyster Crassostrea virginica. The control treatment had no oysters, while the 2 experimental treatments had 2 and 4 oysters added for densities of 7 and 14 ind. $\mathrm{m}^{-2}$, respectively ( $\mathrm{n}=4$ for each treatment). These densities are much higher than modern densities of oysters in Chesapeake Bay, estimated by Newell \& Koch (2004) to be 0.43 ind. $\mathrm{m}^{-2}$, but lower than historical densities, which are estimated to have been as low as 43 ind. $\mathrm{m}^{-2}$ or as high as 150 ind. $\mathrm{m}^{-2}$ in a dense oyster reef habitat (Newell \& Koch 2004).

Expt 4. Expt 4 was carried out for $8 \mathrm{~d}$ from 6 to 14 July. Only 1 experimental treatment of 1 oyster mesocosm ${ }^{-1}$ (4 ind. $\mathrm{m}^{-2}$ ) was contrasted with the control ( $\mathrm{n}=4$ for each treatment).

Expt 5. Expt 5 was the only experiment using blue mussels Mytilus edulis, and was carried out for $14 \mathrm{~d}$ from 26 September to 10 October. The control treatment was contrasted with 2 experimental treatments of 16 and 64 mussels mesocosm ${ }^{-1}$ for densities of 57 and 229 ind. $\mathrm{m}^{-2}$, 
respectively ( $\mathrm{n}=4$ for each treatment). These densities are commonly found in some areas of Long Island, but are much lower than those found in dense mussel beds in nearby Narragansett Bay, Rhode Island (814 to 9943 ind. $\mathrm{m}^{-2}$; Altieri \& Witman 2006).

Statistical analysis. To compare differences in seagrass productivity between treatments, 1-way ANOVAs and Tukey multiple comparison tests were carried out using the program SigmaStat 3.0. The dry weight of epiphytes on the seagrass was normalized by the area of thef seagrass leaves, and also analyzed by treatment for each experiment using a 1-way ANOVA. Since Expts 1 and 4 had only 2 treatments, $t$-tests were used in place of 1-way ANOVAs. Chl a concentrations and light attenuation were analyzed for each experiment using a 2-way repeated-measures ANOVA, with treatment and day as factors. A linear regression was used to examine correlations between leaf area production and light attenuation. All values in text are reported as means $\pm \mathrm{SE}$.

\section{RESULTS}

\section{Expt 1}

The temperature for all mesocosms in Expt 1 was 19.1 $\pm 0.6^{\circ} \mathrm{C}$, and the salinity was $21.96 \pm 0.09$. There was a remarkable difference in chl a concentrations over the course of the experiment between the control, which was $34.08 \pm 9.54 \mu \mathrm{g} \mathrm{l}^{-1}$, and the 'clams' treatment, which was

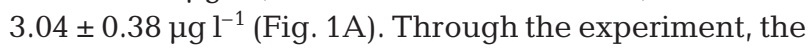
percentage of phytoplankton biomass in the $>5 \mu \mathrm{m}$ size fraction, as measured by chl a, was $33.4 \pm 4.0 \%$ in the control treatment and $38.3 \pm 6.7 \%$ in the 'clams' treatment. The control treatment had greater light attenuation $\left(1.101 \pm 0.139 \mathrm{~m}^{-1}\right)$ than the 'clams' treatment $\left(0.814 \pm 0.190 \mathrm{~m}^{-1}\right.$; Fig. 1B). For this experiment, chl $a$ concentrations and light attenuation varied significantly by treatment (2-way repeated-measures ANOVA, p < 0.001 for chl $a$ and $\mathrm{p}<0.01$ for light attenuation) and by day ( $p<0.001$ for both). Concurrently, the leaf area productivity of the eelgrass in the control treatment $\left(0.318 \pm 0.02 \mathrm{~cm}^{2}\right.$ shoot $\left.^{-1} \mathrm{~d}^{-1}\right)$ was significantly lower than eelgrass Zostera marina productivity in the 'clams' treatment $\left(0.462 \pm 0.04 \mathrm{~cm}^{2}\right.$ shoot $^{-1} \mathrm{~d}^{-1}$; $t$-test, $\mathrm{p}<0.05$; Fig. 1C). The estimated turnover time of the water in the 'clams' treatment was $1.1 \mathrm{~d}$ (Table 1 ).

\section{Expt 2}

The average temperature for all mesocosms in Expt 2 was $20.3 \pm 0.6^{\circ} \mathrm{C}$, and the average salinity was $26.29 \pm$ 0.05 . From Day 2 to 9 , chl a values were consistently low-
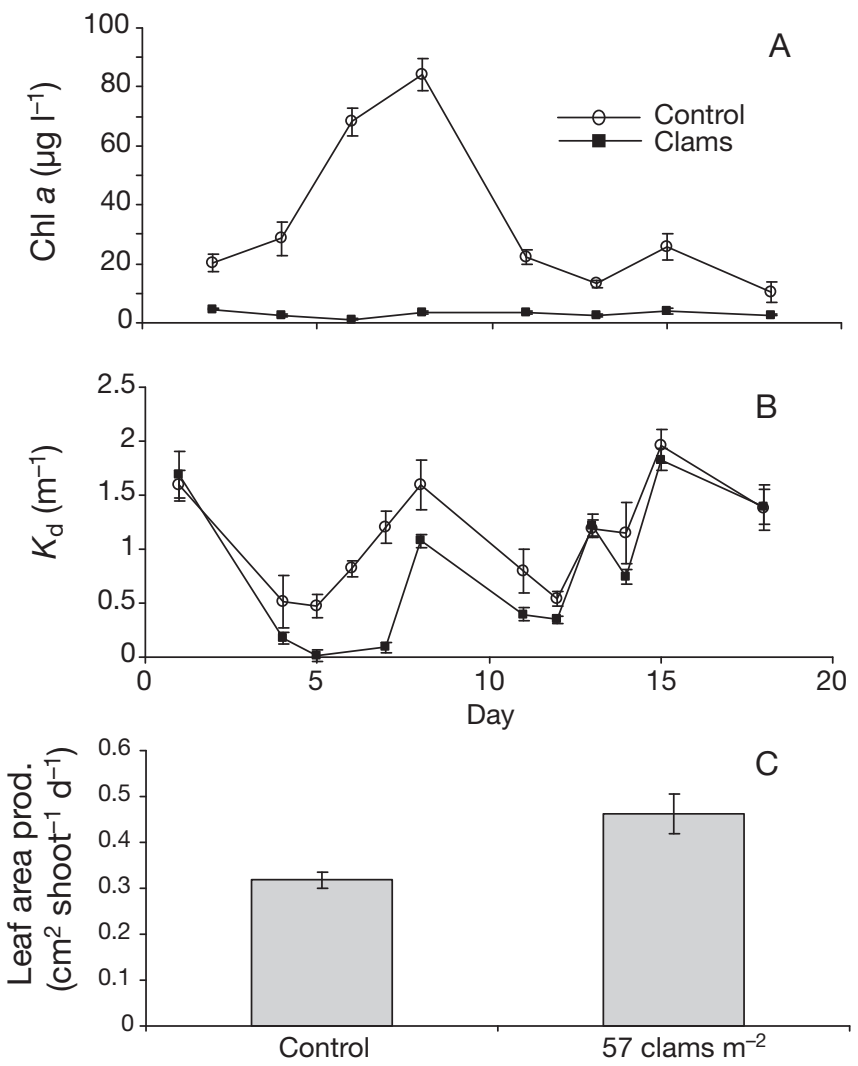

Fig. 1. Temporal changes in (A) chlorophyll a (chl a) and (B) extinction coefficient $\left(K_{\mathrm{d}}\right)$ for Expt 1. (C) Differences in eelgrass Zostera marina leaf area production. Clams are Mercenaria mercenaria. All error bars are $\pm \mathrm{SE}$

est in the high-density clam treatment $(24.31 \pm 7.67 \mu \mathrm{g}$ $\mathrm{l}^{-1}$ ), intermediate in the low-density clam treatment $\left(33.85 \pm 9.85 \mu \mathrm{g} \mathrm{l}^{-1}\right)$, and highest in the control (45.22 \pm $14.33 \mu \mathrm{g} \mathrm{l}^{-1}$; Fig. 2A). The percentage of phytoplankton biomass in the $>5 \mu \mathrm{m}$ size fraction, as measured by chl $a_{\text {, }}$ was $32.2 \pm 2.8 \%$ in the control treatment, $35.2 \pm 3.5 \%$ in the low-density treatment, and $37.6 \pm 4.0 \%$ in the highdensity treatment. Light attenuation showed a similar pattern through Day 8, with $K_{\mathrm{d}}$ being lowest in the highdensity treatment $\left(0.648 \pm 0.158 \mathrm{~m}^{-1}\right)$, intermediate in the low-density treatment $\left(0.813 \pm 0.160 \mathrm{~m}^{-1}\right)$, and highest in the control $\left(0.960 \pm 0.203 \mathrm{~m}^{-1}\right.$; Fig. 2B). Accordingly, chl a concentrations and light attenuation varied significantly by treatment and by day (2-way repeated-measures ANOVA, $p<0.001$ in all cases). The low clam density (14 ind. $\mathrm{m}^{-2}$ ) treatment produced a leaf area productivity $\left(0.832 \pm 0.04 \mathrm{~cm}^{2}\right.$ shoot $\left.^{-1} \mathrm{~d}^{-1}\right)$ similar to that of the high-density $\left(29\right.$ ind. $\left.\mathrm{m}^{-2}\right)$ treatment $(0.806 \pm 0.04$ $\mathrm{cm}^{2}$ shoot $^{-1} \mathrm{~d}^{-1}$ ), but the eelgrass shoots in both clam treatments were significantly more productive than the control treatment $\left(0.642 \pm 0.07 \mathrm{~cm}^{2}\right.$ shoot $^{-1} \mathrm{~d}^{-1}$; Fig. $2 \mathrm{C}_{\text {; }}$ 1 -way ANOVA, $\mathrm{p}<0.05)$. The estimated turnover time was $2.2 \mathrm{~d}$ for the high-density treatment and $4.5 \mathrm{~d}$ for the low-density treatment (Table 1). 
Table 1. Mercenaria mercenaria, Crassostrea virginica, Mytilus edulis. Mean sizes, weights, and ash-free dry weight (AFDW)normalized clearance rates for the 3 bivalve species. Measurements were taken once per species, and mean individual clearance rates were used to estimate turnover times. All measures are means $\pm \mathrm{SE}$

\begin{tabular}{|c|c|c|c|c|}
\hline Bivalve species & $\begin{array}{l}\text { Size (longest shell } \\
\text { dimension, mm) }\end{array}$ & $\begin{array}{c}\text { AFDW } \\
\text { of tissue }(g)\end{array}$ & $\begin{array}{c}\text { Clearance rate measured } \\
\left(\mathrm{l} \mathrm{h}^{-1} \mathrm{~g}^{-1} \text { AFDW }\right)\end{array}$ & $\begin{array}{l}\text { Estimated } \\
\text { turnover time }\end{array}$ \\
\hline $\begin{array}{l}\text { Hard clam (quahog) } \\
\text { Mercenaria mercenaria }\end{array}$ & $52.2 \pm 0.5$ & $1.688 \pm 0.158$ & $0.41 \pm 0.03$ & $\begin{array}{l}14 \text { clams m-2: } 4.5 \mathrm{~d} \\
29 \text { clams m} \mathrm{m}^{-2}: 2.2 \mathrm{~d} \\
57 \text { clams m}{ }^{-2}: 1.1 \mathrm{~d}\end{array}$ \\
\hline $\begin{array}{l}\text { Eastern oyster } \\
\text { Crassostrea virginica }\end{array}$ & $84.5 \pm 1.1$ & $2.564 \pm 0.149$ & $1.91 \pm 0.28$ & $\begin{array}{r}4 \text { oysters } \mathrm{m}^{-2}: 2.5 \mathrm{~d} \\
7 \text { oysters } \mathrm{m}^{-2}: 1.3 \mathrm{~d} \\
14 \text { oysters } \mathrm{m}^{-2}: 0.6 \mathrm{~d}\end{array}$ \\
\hline $\begin{array}{l}\text { Blue mussel } \\
\text { Mytilus edulis }\end{array}$ & $39.0 \pm 0.7$ & $0.195 \pm 0.020$ & $0.289 \pm 0.097$ & $\begin{array}{l}57 \text { mussels m}{ }^{-2}: 14.5 \mathrm{~d} \\
229 \text { mussels m} \mathrm{m}^{-2}: 3.6 \mathrm{~d}\end{array}$ \\
\hline
\end{tabular}
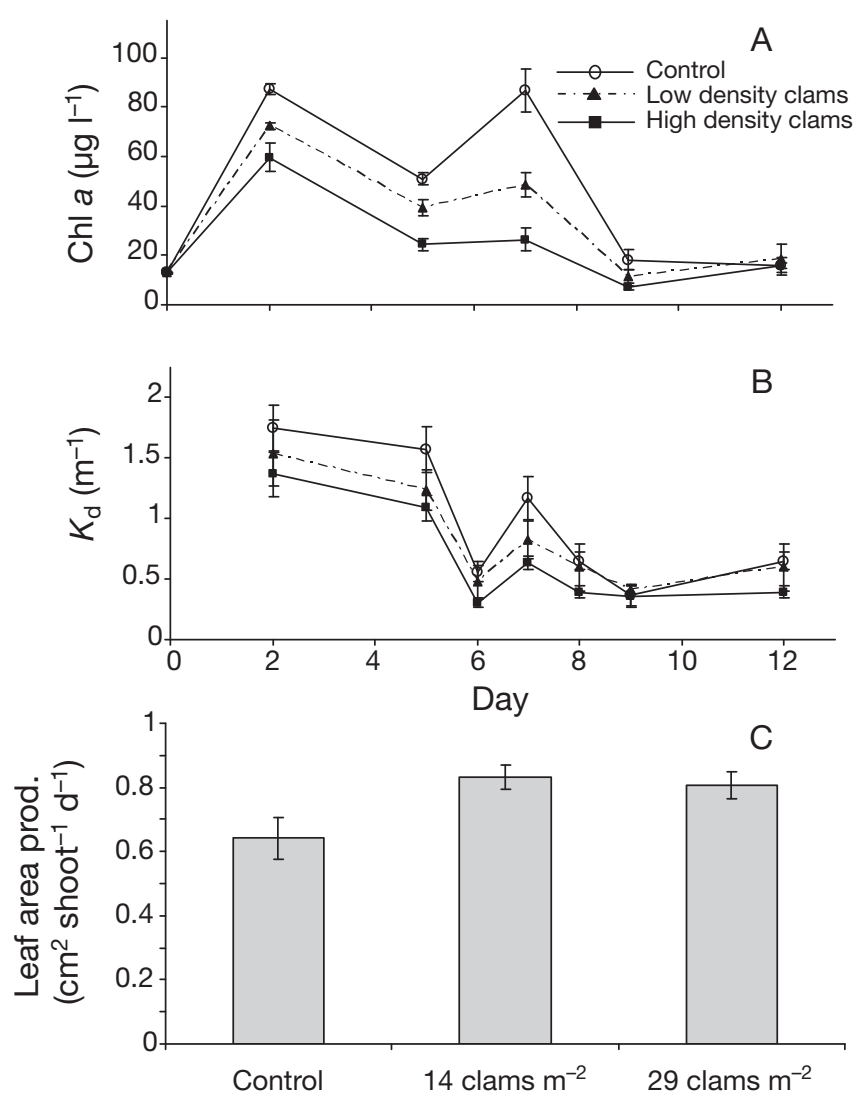

Fig. 2. Temporal changes in (A) chlorophyll a (chl a) and (B) extinction coefficient $\left(K_{\mathrm{d}}\right)$ for Expt 2. (C) Differences in eelgrass Zostera marina leaf area production. Clams are Mercenaria mercenaria. All error bars are \pm SE

\section{Expt 3}

The average temperature for all mesocosms in Expt 3 was $23.2 \pm 0.5^{\circ} \mathrm{C}$, and the average salinity was $24.23 \pm$ 0.56. As in Expt 2, a clear gradation in chl a levels was observed between the high-density $(11.05 \pm 4.18 \mu \mathrm{g}$ $\left.\mathrm{l}^{-1}\right)$ oyster treatment, the low-density $(15.75 \pm 7.40 \mu \mathrm{g}$ $\left.\mathrm{l}^{-1}\right)$ oyster treatment, and the control $(25.64 \pm 9.78 \mu \mathrm{g}$ $\mathrm{l}^{-1}$; Fig. 3A). The percentage of phytoplankton biomass in the $>5 \mu \mathrm{m}$ size fraction, as measured by chl $a$, was $38.0 \pm 1.7 \%$ in the control treatment, $35.2 \pm 3.5 \%$ in the low-density treatment, and $34.0 \pm 2.5 \%$ in the highdensity treatment. Light attenuation had a similarly consistent pattern over Days 1 to $5 ; K_{\mathrm{d}}$ was lowest in the high-density treatment $\left(1.502 \pm 0.268 \mathrm{~m}^{-1}\right)$, intermediate in the low-density treatment (1.586 \pm $\left.0.229 \mathrm{~m}^{-1}\right)$, and highest in the control (1.726 \pm $0.224 \mathrm{~m}^{-1}$; Fig. 3B). Chl a concentrations varied significantly by treatment and by day (2-way repeatedmeasures ANOVA, $\mathrm{p}<0.001$ in both cases); light attenuation varied significantly by treatment over Days 1 to 5 (2-way repeated-measures ANOVA, p < 0.05) and significantly by day (2-way repeated-measures ANOVA, $p<0.001)$. Leaf area productivity was significantly higher in both the low-density $\left(0.495 \pm 0.03 \mathrm{~cm}^{2}\right.$ shoot $\left.^{-1} \mathrm{~d}^{-1}\right)$ and high-density $\left(0.548 \pm 0.02 \mathrm{~cm}^{2}\right.$ shoot $^{-1}$ $\left.\mathrm{d}^{-1}\right)$ treatments than in the control treatment $(0.371 \pm$ $0.03 \mathrm{~cm}^{2}$ shoot ${ }^{-1} \mathrm{~d}^{-1}$; Tukey test, $\mathrm{p}<0.05$ and $\mathrm{p}<0.01$, respectively; Fig. 3C). The estimated turnover times were $0.6 \mathrm{~d}$ for the high-density treatment of oysters and $1.3 \mathrm{~d}$ for the low-density treatment (Table 1).

\section{Expt 4}

The average temperature for all mesocosms in Expt 4 was $24.6 \pm 0.2^{\circ} \mathrm{C}$, and the average salinity was $21.37 \pm$ 0.09 . Expt 4 produced a clear difference between the control and oyster treatment chl a concentrations that was mirrored by changes in algal biomass and light levels. The chl $a$ in the control $\left(49.16 \pm 7.36 \mu^{-1} \mathrm{~g}^{-1}\right)$ was higher than in the oyster treatment $\left(31.82 \pm 4.57 \mathrm{\mu g}^{-1}\right.$; Fig. 4A), while light attenuation was also higher in the control $\left(1.688 \pm 0.094 \mathrm{~m}^{-1}\right)$ than in the oyster treatment $\left(1.239 \pm 0.131 \mathrm{~m}^{-1}\right.$; Fig. 4B). The percentage of phytoplankton biomass in the $>5 \mu \mathrm{m}$ size fraction, as measured by chl $a$, was $34.3 \pm 4.7 \%$ in the control treatment and $28.4 \pm 4.4 \%$ in the oyster treatment. Chl $a$ 

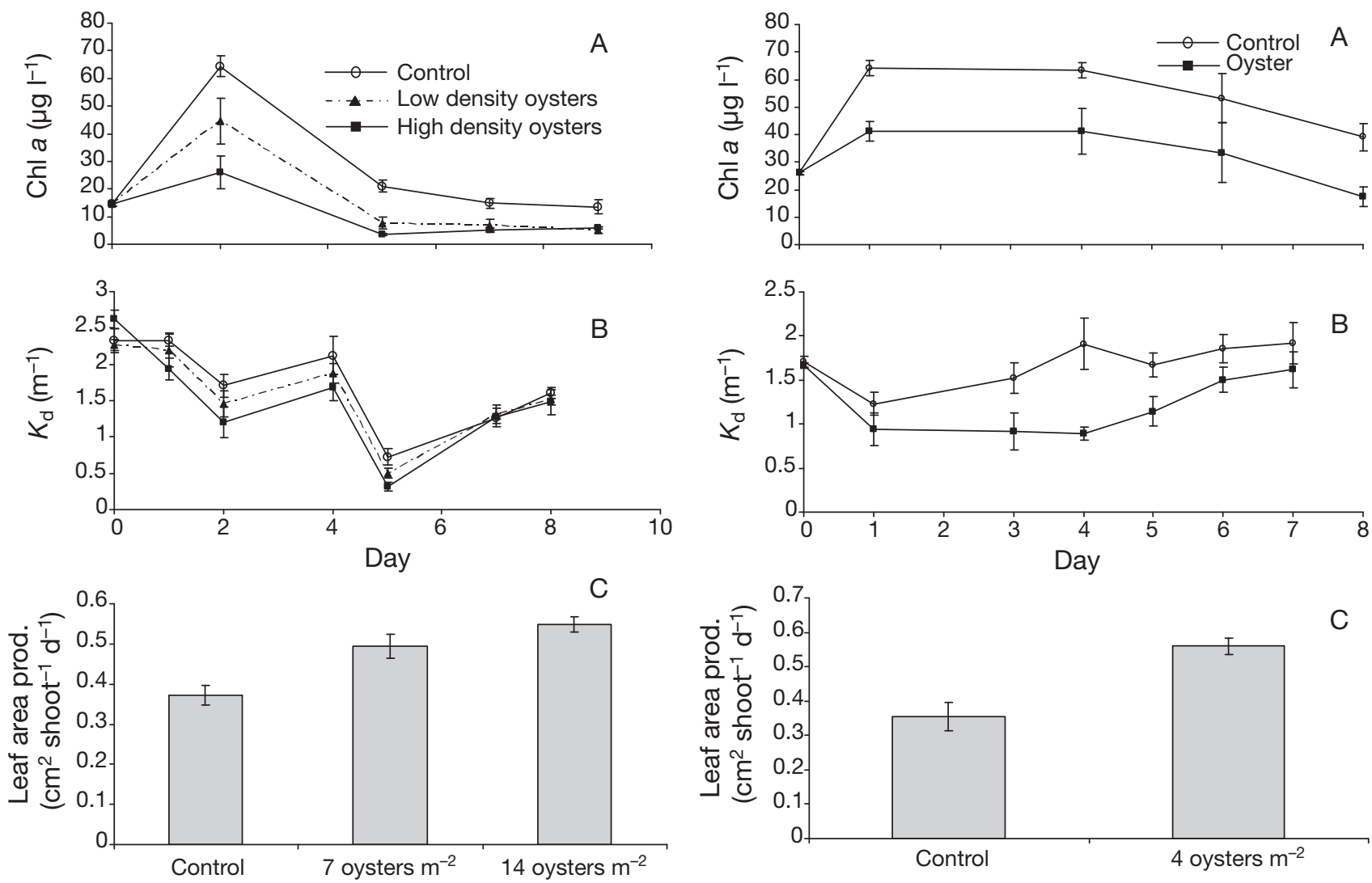

Fig. 3. Temporal changes in (A) chlorophyll a (chl a) and (B) extinction coefficient $\left(K_{\mathrm{d}}\right)$ for Expt 3. (C) Differences in eelgrass Zostera marina leaf area production. Oysters are Crassostrea virginica. All error bars are $\pm \mathrm{SE}$

concentrations varied significantly by treatment and by day (2-way repeated-measures ANOVA, p $<0.05$ and $\mathrm{p}<0.01$, respectively). Light attenuation also varied between treatments and by day (2-way repeatedmeasures ANOVA, $\mathrm{p}<0.05$ and $\mathrm{p}<0.001$, respectively). Leaf area productivity was significantly higher in the experimental treatments with 1 oyster $(0.560 \pm$ $0.02 \mathrm{~cm}^{2}$ shoot $^{-1} \mathrm{~d}^{-1}$ ) than in the control treatments $\left(0.355 \pm 0.04 \mathrm{~cm}^{2}\right.$ shoot $^{-1} \mathrm{~d}^{-1}$; 2-tailed $t$-test, $\mathrm{p}<0.01$; Fig. 4C). The turnover time for the oyster treatment was $2.5 \mathrm{~d}$ (Table 1$)$.

\section{Expt 5}

The average temperature for all mesocosms in Expt 5 was $19.3 \pm 0.7^{\circ} \mathrm{C}$, and the average salinity was $28.88 \pm$ 0.09. Unlike Expts 2 and 3, there was not a consistent relationship between mussel density and chl a levels; chl a was actually higher in the low-density treatment than in the control treatment on Day 7. The high-density mussel treatment, however, had consistently lower

Fig. 4. Temporal changes in (A) chlorophyll a (chl a) and (B) extinction coefficient $\left(K_{\mathrm{d}}\right)$ for Expt 4 . (C) Differences in eelgrass Zostera marina leaf area production. Oysters are Crassostrea virginica. All error bars are $\pm \mathrm{SE}$

chl a $\left(15.45 \pm 5.40 \mu \mathrm{g} \mathrm{l}^{-1}\right)$ than the low-density $(40.11 \pm$ $\left.8.16 \mu \mathrm{g} \mathrm{l}^{-1}\right)$ and the control $\left(40.37 \pm 7.43 \mu \mathrm{g} \mathrm{l}^{-1}\right.$; Fig. 5A) treatments. The percentage of phytoplankton biomass in the $>5 \mu \mathrm{m}$ size fraction, as measured by chl $a$, was $24.8 \pm 5.2 \%$ in the control treatment, $29.2 \pm 2.5 \%$ in the low-density treatment, and $14.2 \pm 5.4 \%$ in the highdensity treatment. Chl a levels varied significantly by treatment and by day (2-way repeated-measures ANOVA, $\mathrm{p}<0.05$ and $\mathrm{p}<0.001$, respectively). Unfortunately, we were not able to obtain light data for Expt 5, although the water in the high-density mussel treatment was visibly clearer to than that the low-density treatment and the control. Leaf area productivity was $0.790 \pm 0.11 \mathrm{~cm}^{2}$ shoot $^{-1} \mathrm{~d}^{-1}$ in the treatments with a high density (229 ind. $\mathrm{m}^{-2}$ ) of mussels, $0.435 \pm 0.02 \mathrm{~cm}^{2}$ shoot ${ }^{-1} \mathrm{~d}^{-1}$ in the low-density (57 ind. $\mathrm{m}^{-2}$ ) treatment, and $0.399 \pm 0.08 \mathrm{~cm}^{2}$ shoot $^{-1} \mathrm{~d}^{-1}$ in the control treatment (Fig. 5B). The productivity was significantly higher in the high-density treatment, but did not significantly differ between the low-density and the control treatments (1-way ANOVA and Tukey multiple comparison, $\mathrm{p}<0.05$ ). The estimated turnover times 

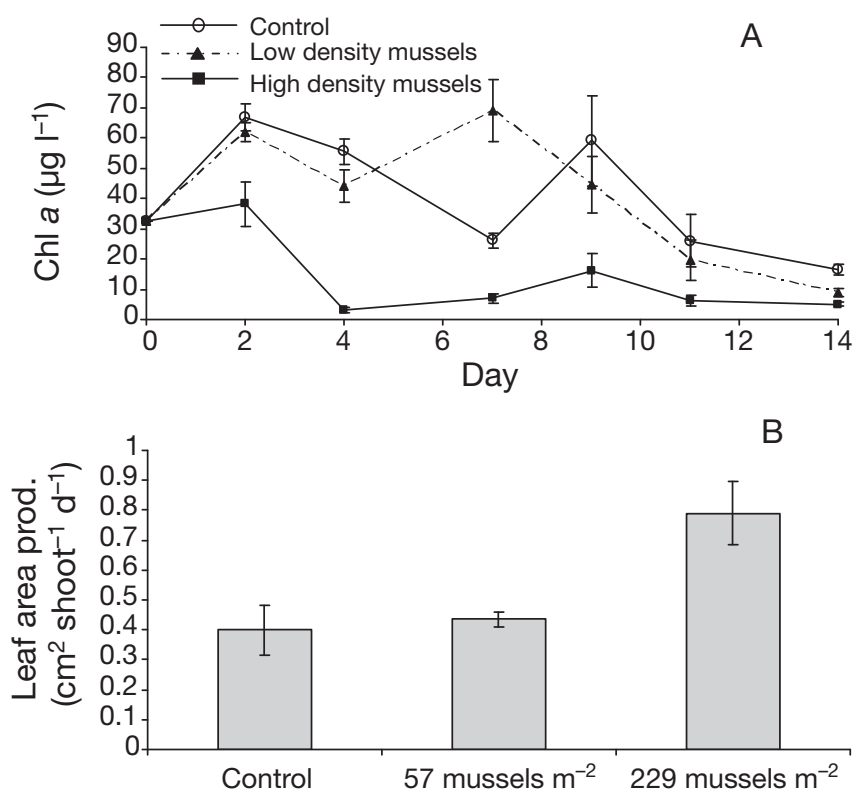

Fig. 5. Temporal changes in (A) chlorophyll a (chl a) for Expt 5. (B) Differences in eelgrass Zostera marina leaf area production. Mussels are Mytilus edulis. All error bars are $\pm \mathrm{SE}$

were $3.6 \mathrm{~d}$ for the high density of mussels and $14.5 \mathrm{~d}$ for the low density of mussels (Table 1).

\section{Bivalve filtration rates, turnover times, and facilitation of eelgrass productivity}

Length, weight, and clearance rate measurements were recorded for each group of bivalves (Table 1). In all cases, the bivalves filtered from the control treatment mesocosms at a significant rate (Table 1). Crassostrea virginica, which had the highest individual and weight-specific clearance rates $\left(1.91 \pm 0.97 \mathrm{l} \mathrm{h}^{-1} \mathrm{~g}^{-1}\right.$ AFDW), produced the shortest estimates for mesocosm turnover time (0.6 to $2.5 \mathrm{~d}$; Table 1$)$, followed by Mercenaria mercenaria (clearance rate $=0.41 \pm 0.24 \mathrm{l} \mathrm{h}^{-1}$ $\mathrm{g}^{-1}$ AFDW; turnover time $=1.1$ to $4.5 \mathrm{~d}$ ), and Mytilus edulis (clearance rate $=0.29 \pm 0.29 \mathrm{l} \mathrm{h}^{-1} \mathrm{~g}^{-1}$ AFDW; turnover time $=3.6$ to $14.5 \mathrm{~d}$ ). Epibiont biomass, as measured by milligrams AFDW of epibionts per square centimeter of leaf area, did not differ significantly among treatments in any experiment (data not shown).

During our experiments, higher densities of bivalves produced dramatic decreases in water column chl a over the course of each experiment (Figs. 1A, 2A, 3A, $4 \mathrm{~A}, \& 5 \mathrm{~A})$. Exps 1 to 4 also had significant decreases in light attenuation in the treatments with bivalves (Figs. 1B, 2B, 3B, \& 4B). There was a significant inverse correlation (Fig. 6 ; $\mathrm{r}^{2}=0.400, \mathrm{p}<0.001$ ) between leaf area productivity and mean light attenuation coefficient for

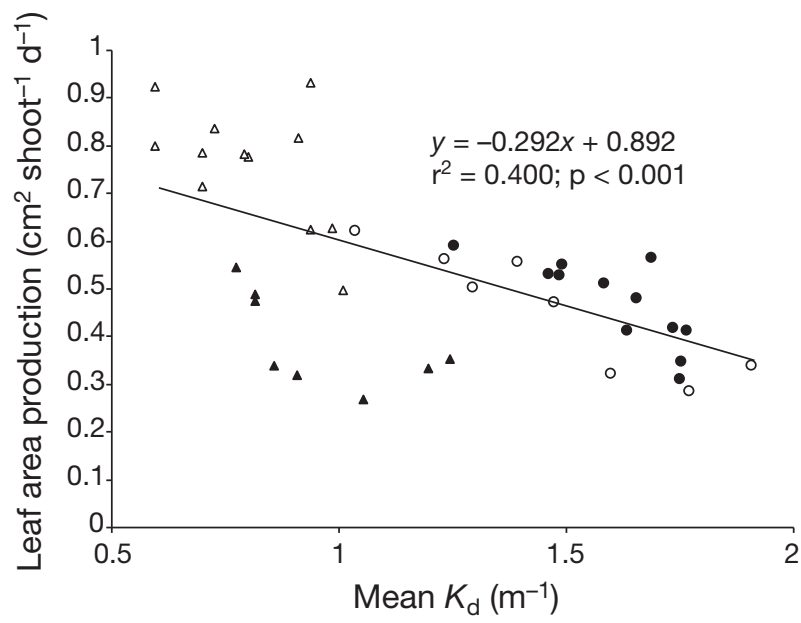

Fig. 6. Changes in leaf area productivity of eelgrass Zostera marina as a function of mean $K_{\mathrm{d}}$ for all tanks from Expts 1 to 4 .

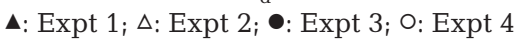

Exps 1 to 4 (light attenuation data were not available for Expt 5). There was also a significant inverse correlation between mesocosm turnover time (Table 1) and leaf area productivity among all experiments $\left(y=-0.015 x+0.647, \mathrm{r}^{2}=0.21, \mathrm{p}<0.05\right.$; regression not shown).

\section{DISCUSSION}

This study has demonstrated, through a series of mesocosm experiments, that suspension-feeding bivalves can facilitate the growth of eelgrass Zostera marina. Over the course of 5 experiments, the effects of 3 densities of Mercenaria mercenaria, 3 densities of Crassostrea virginica, and 2 densities of Mytilus edulis were examined. In all cases, the highest density of bivalves produced significant decreases in chl $a_{\text {, in- }}$ creases in light penetration, and significant increases in leaf area productivity of $Z$. marina. On average, eelgrass growth increased by $48 \pm 9.3 \%$ in the presence of moderate densities of bivalves relative to control treatments. For $M$. mercenaria and $C$. virginica, intermediate or even low densities of these species filtered sufficiently to alter light and chl a levels to the benefit of eelgrass productivity. The results of these experiments help to refine our understanding of the function of filter-feeding bivalves in estuarine ecosystems.

Some studies have suggested that suspensionfeeding bivalves control eutrophication and algal blooms (Cloern 1982, Officer et al. 1982, Cerrato et al. 2004) or significantly alter carbon cycling (Doering et al. 1986). Newell \& Koch's (2004) modeling study predicted that filtration by bivalves could benefit seagrass. 
To our knowledge, this is the first study that demonstrates the facilitation of eelgrass growth by the filtration of bivalves in an experimental setting. The mechanism of facilitation is an increase in light penetration (Figs. 1B, 2B, 3B, \& 4B), paired with dramatic reductions in the standing stocks of phytoplankton (Figs. 1A, 2A, 3A, 4A, \& 5A), due to the bivalves' clearance of the water column. Other studies (Reusch et al. 1994, Peterson \& Heck 2001) have demonstrated that nutrient fertilization by bivalves through biodeposition can enhance growth of seagrass. Peterson \& Heck's (2001) study was carried out in St. Joseph Bay, Florida, an oligotrophic environment where light was plentiful and nutrients were scarce. Because of the eutrophic nature of a great number of estuaries (Nixon 1995, de Jonge et al. 2002, Kemp et al. 2005, Valiela 2006), mitigation of light limitation may be an even more common mechanism by which bivalve filtration benefits seagrass populations. This study was not designed to separate the relative contributions of nutrientfertilization and water-transparency effects on seagrasses by bivalves in eutrophic estuaries.

During our experiments, higher densities of bivalves produced dramatic decreases in water column chl a and light attenuation (Figs. 1 to 5), and there was a significant inverse correlation (Fig. $6 ; r^{2}=0.400$, p < 0.001) between leaf area productivity and mean light attenuation coefficient. The decreases in chl $a$, increases in light penetration, and correlation between leaf area productivity and light levels suggest that the principle effect of the bivalves on eelgrass growth was mediated by clearing of the water column, leading to increased light penetration. During our experiments, chl a levels tended to decrease $\left(\leq 20 \mu \mathrm{g} \mathrm{I}^{-1}\right)$ toward the end of each experiment in all treatments (Figs. 1A, 2A, 3A, 4A, \& $5 \mathrm{~A})$, likely due to the development of high levels of algal biomass (> $60 \mu \mathrm{g} \mathrm{l}^{-1}$ ) in control tanks whose nutrient demand greatly exceeded our nutrient loading rate (10 $\mu \mathrm{M}$ ammonium and $0.625 \mu \mathrm{M}$ orthophosphate daily). Had our nutrient loading rate increased concurrently with increasing algal biomass to sustain the high biomass levels throughout the experiment, the significant differences in seagrass productivity between control and shellfish treatments would have likely been even larger than those observed (Figs. 1C, 2C, $3 \mathrm{C}, 4 \mathrm{C}, \& 5 \mathrm{~B})$.

The depth of the water column in our experiments was $1.2 \mathrm{~m}$, a depth comparable to some northeast United States lagoons such as Great South Bay, Waquoit Bay (Valiela et al. 1992), and Barnegat Bay (Bologna et al. 2005), or European estuaries such as the Wadden Sea (Smaal \& Prins 1993), but shallower than systems such as Chesapeake Bay (Kemp et al. 2005), San Francisco Bay (Officer et al. 1982), or the Baltic Sea (Smaal \& Prins 1993). Smaal \& Prins (1993) sur- veyed bivalve suspension feeding in several European estuaries and defined 'filtration pressure' as the ratio of bivalve consumption to phytoplankton production in the overlying water column. Obviously, as the water column depth increases, the density of benthic suspension feeders required to balance the production in the overlying water column also increases. Smaal \& Prins (1993) suggested that a density of from 2 to $8 \mathrm{~g}$ AFDW bivalve tissue $\mathrm{m}^{-3}$ of water column was enough for bivalve suspension feeders to exert a strong influence on the overlying water column. Our experimental bivalve densities ( 7.5 to $79.1 \mathrm{~g} \mathrm{AFDW} \mathrm{m}^{-3}$ ) met or exceeded this range of biomass, indicating that all of our experimental bivalve densities should have been able to clear the volume of the mesocosms. The lowest density of mussels, which did not exert a significant influence on chl $a$, light, or eelgrass growth, had a biomass of $9.1 \mathrm{~g} \mathrm{AFDW} \mathrm{m}^{-3}$, above Smaal \& Prins' (1993) mass requirement. This suggests that the individual or weight-specific clearance rate of a given suspension feeder may be more important than the total biomass or that lower temperatures present during this final experiment contributed to lower filtration rates.

Some recent studies have focused on the turnover time, or clearance time, for suspension feeders to filter the volume of a body of water (Cerrato et al. 2004, Newell \& Koch 2004, Bologna et al. 2005). In a previous mesocosm experiment with Mercenaria mercenaria, Cerrato et al. (2004) found that clearance times of 0.51 to $2.4 \mathrm{~d}$ were sufficient to prevent the development of dense brown-tide blooms, while blooms proliferated at clearance times of $3.7 \mathrm{~d}$ or longer. Our clearance times, based upon the measured clearance rates of bivalves used in our experiments, ranged from $0.64 \mathrm{~d}$ for our highest density of oysters to $14.5 \mathrm{~d}$ for our lowest density of mussels (Table 1). Interestingly, at the longest clearance time of $14.5 \mathrm{~d}$, chl a levels and eelgrass growth in the low-density mussel treatment were not significantly different from values in the control. The clearance time $(4.5 \mathrm{~d})$ for the lowest density of hard clams, while longer than the critical values in Cerrato et al.'s (2004) study, did produce a significant decrease in chl $a$ and a significant increase in eelgrass growth. All other clearance times were $\leq 3.6 \mathrm{~d}$ and also produced significant increases in eelgrass growth. Since these clearance times are based on clearance measurements for bivalves placed in water with high algal biomass (>20 $\mathrm{gg}$ chl a $\mathrm{l}^{-1}$ ), clearance rates for bivalves feeding at lower concentrations of chl a may have been higher (Clausen \& Riisgard 1996).

The results of these mesocosm experiments, combined with the work of Cloern (1982), Officer et al. (1982), Cerrato et al. (2004), Newell \& Koch (2004), and many others, suggest dense communities of benthic suspension feeders can control the negative effects of 
eutrophication. Clearly, this benefits seagrass productivity through increased light penetration (Figs. 1C, $2 \mathrm{C}, 3 \mathrm{C}, 4 \mathrm{C}, \& 5 \mathrm{~B})$. There are likely many other synergistic interactions between bivalves and seagrasses that facilitate growth and recruitment of both clades, perhaps to the benefit of entire ecosystems. Bivalves clear the water column and increase light penetration for seagrasses and benthic diatoms (Lotze et al. 2006), while seagrasses provide habitat, predation refuges, and a benthic source of oxygen for bivalves and other organisms (Valiela et al. 1992, Reise 2002, Bruno et al. 2003, Bologna et al. 2005). Bivalves also fertilize seagrass roots through biodeposition (Peterson \& Heck 1999, 2001). Seagrasses can minimize benthic nutrient fluxes to the water column by stabilizing sediments and absorbing benthic nutrients (Reise 2002, Bruno et al. 2003). These effects can work, together with bivalve filtration, to reduce suspended sediment load and minimize pelagic phytoplankton abundances (Newell \& Koch 2004, Lotze et al. 2006).

Recently, Pomeroy et al. (2006) have suggested that oyster restoration would be unlikely to counter the effects of eutrophication in Chesapeake Bay, Maryland, USA, due to temporal and spatial decoupling of bivalve filtration pressure and algal blooms in this system. While they present several valid arguments, these points do not apply to the current study for the following reasons. Our mesocosms were meant to mimic a shallow, lagoon-type estuary, such as Long Island's (New York, USA) south shore estuaries, which have a mean depth of $1.2 \mathrm{~m}$ (Wilson et al. 1991). In these systems, the water column is chronically well-mixed (Wilson et al. 1991) and bivalves are evenly distributed (Weiss et al. 2007), suggesting bivalves, algal blooms, and seagrasses should be more spatially coupled than in Chesapeake Bay. In addition, eelgrass growth and maximum bivalve filtration rates coincide during late spring through fall months (Grizzle et al. 2001, Hemminga \& Duarte 2001), providing a close temporal link between bivalves and eelgrass in temperate lagoonal systems.

A productive, high-biomass benthic community seems to be one of the hallmarks of a healthy estuary, and many anthropogenic insults drive estuaries into phytoplankton- and microbial-dominated systems at the expense of the benthic community (Jackson 2001, Kemp et al. 2005, Lotze et al. 2006). These experiments indicate that a healthy benthos (robust bivalves and seagrass populations) is more resistant to eutrophication than seagrass alone. Estuaries become more vulnerable to eutrophication, algal blooms, hypoxia, and degradation of benthic habitats when overharvesting or habitat loss removes the filtration pressure of bivalves. For example, Cerco \& Noel's (2007) modeling study predicted a 10-fold increase in oyster biomass in Chesapeake Bay would lead to decreases in phyto- plankton biomass and benthic nutrient fluxes and to increases in dissolved oxygen and submerged aquatic vegetation.

The bivalve densities used in our mesocosms (14 to 57 clams $\mathrm{m}^{-2}$ and 4 to 14 oysters $\mathrm{m}^{-2}$ ) were higher than current densities in many United States estuaries such as Great South Bay or Chesapeake Bay, but were lower than historical densities found in these same systems (53 to 105 clams $\mathrm{m}^{-2}$ and 43 to 150 oysters $\mathrm{m}^{-2}$, respectively; Cerrato et al. 2004, Newell \& Koch 2004). Jackson (2001) and Lotze et al. (2006) surveyed historical declines across a broad suite of organisms and habitats, and found that overharvesting and habitat destruction preceded eutrophication in most estuaries. As such, it would seem successful management efforts will need to take an 'ecosystem-based' approach that incorporates habitat conservation, shellfish restoration, and restrictions on nutrient loading to restore healthy estuarine function. In light of the results from the present study, it appears that even a partial recovery of shellfish populations could help combat eutrophication and have a beneficial impact on seagrass habitats in shallow, eutrophied estuaries.

Acknowledgements. Many people provided field and laboratory support for this project including A. Burson, T. Donoghue, B. Rodgers, T. Davis, L. Moore, J. Carroll, F. Koch, J. Goleski, T. Duffy, K. Rountos, A. Fournier, M. Meade, and D. Getz. Two anonymous reviewers provided many insightful comments and suggestions. This project was supported by grants from New York Sea Grant and the Tamarind Foundation. This is Contribution No. 1345 from the Marine Sciences Research Center, School of Marine and Atmospheric Sciences at Stony Brook University.

\section{LITERATURE CITED}

Altieri AH, Witman JD (2006) Local extinction of a foundation species in a hypoxic estuary: integrating individuals to ecosystem. Ecology 87:717-730

Bintz JC, Nixon SW (2001) Responses of eelgrass Zostera marina seedlings to reduced light. Mar Ecol Prog Ser 223:133-141

Bintz JC, Nixon SW, Buckley BA, Granger SL (2003) Impacts of temperature and nutrients on coastal lagoon plant communities. Estuaries 26:765-776

Bologna PAX, Fetzer ML, McDonnell S, Moody EM (2005) Assessing the potential benthic-pelagic coupling in episodic blue mussel (Mytilus edulis) settlement events within eelgrass (Zostera marina) communities. J Exp Mar Biol Ecol 316:117-131

$>$ Bruno JF, Stachowicz JJ, Bertness MD (2003) Inclusion of facilitation into ecological theory. Trends Ecol Evol 18: 119-125

Brush MJ, Nixon SW (2002) Direct measurements of light attenuation by epiphytes on eelgrass Zostera marina. Mar Ecol Prog Ser 238:73-79

Cerco CF, Noel MR (2007) Can oyster restoration reverse cultural eutrophication in Chesapeake Bay? Estuaries Coasts 30:331-343 
Cerrato RM, Caron DA, Lonsdale DJ, Rose JM, Schaffner RA (2004) Effect of the northern quahog Mercenaria mercenaria on the development of blooms of the brown tide alga Aureococcus anophagefferens. Mar Ecol Prog Ser 281:93-108

Clausen I, Riisgard HU (1996) Growth, filtration and respiration in the mussel Mytilus edulis: no evidence for physiological regulation of the filter-pump to nutritional needs. Mar Ecol Prog Ser 141:37-45

Cloern JE (1982) Does the benthos control phytoplankton biomass in south San Francisco Bay? Mar Ecol Prog Ser 9: 191-202

de Jonge VN, Elliott M, Orive E (2002) Causes, historical development, effects and future challenges of a common environmental problem: eutrophication. Hydrobiologia 475-476:1-19

Dennison WC, Alberte RS (1985) Role of daily light period in the depth distribution of Zostera marina (eelgrass). Mar Ecol Prog Ser 25:51-61

Dennison WC, Marshall GJ, Wigand C (1989) Effects of 'brown tide' shading on eelgrass (Zostera marina) distributions. In: Cosper EM, Bricelj VM, Carpenter EJ (eds) Novel phytoplankton blooms: causes and impacts of recurrent brown tides and other unusual blooms. Springer-Verlag, Berlin, p 675-692

Doering PH, Oviatt CA, Kelly JR (1986) The effects of the filter-feeding clam Mercenaria mercenaria on carbon cycling in experimental marine mesocosms. J Mar Res 44:839-861

Duarte CM (1995) Submerged aquatic vegetation in relation to different nutrient regimes. Ophelia 41:87-112

Gobler CJ, Boneillo GE (2003) Impacts of anthropogenically influenced groundwater seepage on water chemistry and phytoplankton dynamics within a coastal marine system. Mar Ecol Prog Ser 255:101-114

Gobler CJ, Lonsdale DJ, Boyer GL (2005) A review of the causes, effects, and potential management of harmful brown tide blooms caused by Aureococcus anophagefferens (Hargraves et Sieburth). Estuaries 28:726-749

Grizzle RE, Bricelj VM, Shumway SE (2001) Physiological ecology of Mercenaria mercenaria. In: Kraeuter JN, Castagna M (eds) Biology of the hard clam. Elsevier Science, Amsterdam, p 305-382

Hauxwell J, Cebrian J, Furlong C, Valiela I (2001) Macroalgal canopies contribute to eelgrass (Zostera marina) decline in temperate estuarine ecosystems. Ecology 82: 1007-1022

Heath RT, Fahnenstiel GL, Gardner WS, Cavaletto JF, Hwang SJ (1995) Ecosystem-level effects of zebra mussels (Dreissena polymorpha): an enclosure experiment in Saginaw Bay, Lake Huron. J Great Lakes Res 21:501-516

> Heck KL, Wetstone GS (1977) Habitat complexity and invertebrate species richness and abundance in tropical seagrass meadows. J Biogeogr 4:135-142

Hemminga MA, Duarte CM (2001) Seagrass ecology. Cambridge University Press, Cambridge

Jackson JBC (2001) What was natural in the coastal oceans? Proc Natl Acad Sci USA 98:5411-5418

Kemp WM, Boynton WR, Adolf JE, Boesch DF and others (2005) Eutrophication of Chesapeake Bay: historical trends and ecological interactions. Mar Ecol Prog Ser 303:1-29
Lotze HK, Lenihan HS, Bourque BJ, Bradbury RH and others (2006) Depletion, degradation, and recovery potential of estuaries and coastal seas. Science 312:1806-1809

Newell RIE, Koch EW (2004) Modeling seagrass density and distribution in response to changes in turbidity stemming from bivalve filtration and seagrass sediment stabilization. Estuaries 27:793-806

Nixon SW (1995) Coastal marine eutrophication-a definition, social causes, and future concerns. Ophelia 41: $199-219$

Officer CB, Smayda TJ, Mann R (1982) Benthic filter feeding: a natural eutrophication control. Mar Ecol Prog Ser 9: 203-210

Parsons TR, Maita Y, Lalli CM (1984) A manual of chemical and biological methods for seawater analysis. Pergamon Press, Oxford

Peterson BJ, Heck KL Jr (1999) The potential for suspension feeding bivalves to increase seagrass productivity. J Exp Mar Biol Ecol 240:37-52

Peterson BJ, Heck KL Jr (2001) An experimental test of the mechanism by which suspension feeding bivalves elevate seagrass productivity. Mar Ecol Prog Ser 218:115-125

Pomeroy LR, D'Elia CF, Schaffner LC (2006) Limits to topdown control of phytoplankton by oysters in Chesapeake Bay. Mar Ecol Prog Ser 325:301-309

Reise K (2002) Sediment mediated species interactions in coastal waters. J Sea Res 48:127-141

Reusch TBH, Chapman ARO, Groger JP (1994) Blue mussels Mytilus edulis do not interfere with eelgrass Zostera marina but fertilize shoot growth through biodeposition. Mar Ecol Prog Ser 108:265-282

Riisgard HU (2001) On measurement of filtration rates in bivalves-the stony road to reliable data: review and interpretation. Mar Ecol Prog Ser 211:275-291

Smaal AC, Prins TC (1993) The uptake of organic matter and the release of inorganic nutrients by bivalve suspension feeder beds. In: Dame RF (ed) Bivalve filter feeders in estuarine and coastal ecosystem processes. SpringerVerlag, Berlin, p 271-298

Sokal RR, Rohlf FJ (1995) Biometry. WH Freeman, New York

Taylor DI, Nixon SW, Granger SL, Buckley BA (1999) Responses of coastal lagoon plant communities to levels of nutrient enrichment: a mesocosm study. Estuaries 22:1041-1056

Valiela I (2006) Global coastal change. Blackwell Publishing, Boston, MA

Valiela I, Foreman K, Lamontagne M, Hersh D and others (1992) Couplings of watersheds and coastal waters sources and consequences of nutrient enrichment in Waquoit Bay, Massachusetts. Estuaries 15:443-457

Weiss MB, Curran PB, Peterson BJ, Gobler CJ (2007) The influence of plankton composition and water quality on hard clam (Mercenaria mercenaria L.) populations across Long Island's south shore lagoon estuaries. J Exp Mar Biol Ecol 345:12-25

Wilson RE, Wong KC, Carter HH (1991) Aspects of circulation and exchange in Great South Bay. In: Schubel JR, Bell TM Carter HH (eds) The Great South Bay. SUNY Press, Albany, NY, p 33-42

Zieman JC (1974) Methods for study of growth and production of turtle grass, Thalassia testudinum Konig. Aquaculture 4:139-143

Submitted: March 6, 2007; Accepted: October 16, 2007

Proofs received from author(s): March 17, 2008
Editorial responsibility: Kenneth Heck,

Dauphin Island, Alabama, USA 